九州大学学術情報リポジトリ

Kyushu University Institutional Repository

\title{
Study on Trends and Characteristics of Timber Supply and Demand in Korea
}

Kang, Hag Mo

Department of Forest Environmental Science, Chonbuk National University

Choi, Soo Im

Department of Forest Resources, Sunchon National University

Sato, Noriko

Laboratory of Forest Policy, Division of Forest Environment and Management Sciences,

Department of Agro-environmental Sciences, Faculty of Agriculture, Kyushu University

https://doi.org/10.5109/1543426

出版情報：九州大学大学院農学研究院紀要. 60 (2)，pp.543-552，2015-09-18. Faculty of Agriculture, Kyushu University

バージョン :

権利関係 : 


\title{
Study on Trends and Characteristics of Timber Supply and Demand in Korea
}

\author{
Hag Mo KANG ${ }^{1}$, Soo Im $\mathrm{CHOI}^{2 *}$ and Noriko SATO \\ Laboratory of Forest Policy, Division of Forest Environment and Management Sciences, \\ Department of Agro-environmental Sciences, Faculty of Agriculture, \\ Kyushu University, Fukuoka 812-8581, Japan \\ (Received May 7, 2015 and accepted May 19, 2015)
}

\begin{abstract}
Timber consumption in Korea reached around 27 million $\mathrm{m}^{3}$ a year while the self-sufficiency rate for timber is only $16.2 \%$. Although the rate has been increasing gradually due to recent afforestation projects and renewal of tree species that increased the production of domestic timber, domestically produced timber is mostly small-diameter logs and Korea still depends on imports for large-diameter logs. For the import of log, New Zealand which represents Radiatapine species accounts for as much as 68\% (as of 2013) of the total log import. Contrary to the recent decrease of log imports, the import of timber products such as sawn timber has increased continuously; however, log is still major import item as the sawn timber accounts for $30 \%$ of $\log$ and sawn timber imports. On the other hand, PB and MDF are showing strong competitive relationship with plywood in Korea. From the 2000's, the domestic production and market scale of PB and MDF are expanding due to the increasing use of timber as interior materials following the demand for qualitative enhancement of residential environment along with the economic development. Especially, MDF accounts for $57 \%$ of timber board (plywood, PB, MDF) production.
\end{abstract}

Key words: timber supply and demand, log, sawn timber, plywood, PB, MDF

\section{INTRODUCTION}

Timber is a natural resource used for various purposes from processing of wood products to non-timber use such as the use as an element of public property and is quite closely related with living. Since timber is used as the raw material for plywood, sawn wood, particle board (PB), and so forth after lumbering, timber supply and demand relation has a great impact on overall wood industry. Also, Forest before lumbering plays various roles such as the storage of water resources, recreation and health, and preservation of biodiversity. In other words, it is quite important to understand the characteristics and trends of timber supply and demand as timber, which is closely related with living and wood industry, and its significance has been gradually increasing (Lee et al., 2008; Lee et al., 2013).

Korea is a net timber importer and heavily depends on imported timber for its self-sufficiency for timber remains below $20 \%$ of log production although more than $64 \%$ of the total land area of Korea is forest. This is because the afforestation to secure resources began in the late 1960's after the forest resources were devastated by the Korean War and the plywood industry which was the central industry of domestic timber industry before the 1980's had imported a large amount of hardwood tree logs to manufacture and export plywood (Choi et al., 2001).

However, timber supply and demand structure in Korea underwent a great change in the 1980's when the

\footnotetext{
1 Department of Forest Environmental Science, Chonbuk National University, Chonju, 561-756, Korea

2 Department of Forest Resources, Sunchon National University, Suncheon, 540-950, Korea

* Corresponding author (E-mail: sooim@sunchon.ac.kr)
}

forest resource in Southeast Asian countries began to develop their down forest industry and reduced lumbering and to protect environment and began to put an embargo on log export (Korea Forest Research Institute, 2007). This rapidly reduced the import of tropical hardwood log and deteriorated domestic plywood industry's competitive strength in the overseas market which rapidly increased the import of plywood. It also brought great changes to the timber import structure such as the increase of New Zealand's conifer logs in the 1990's. Domestically, the financial crisis at the end of 1997 deteriorated Korean economy and greatly influenced the timber supply and demand (Choi et al., 2001). The recession in the construction business from the end of the 1990's and the increase of wood products also brought great changes to timber supply and demand structure in Kore (Min et al., 2011).

As described above, changes in external circumstances as well as domestic economic conditions have greatly influenced the timber supply and demand structure. In Korea, timber supply and demand was mostly studied around the 2000's and recently only few studies were performed on the timber supply and demand structure (Jeong et al., 1997; Joo et al., 1998; Joo, 2004).

Therefore, this study intended to analyze the trend and characteristics of timber supply and demand in Korea by focusing on timber production, import, and export regarding.

\section{MATERIALS AND METHODS}

Time series statistical data and investigation reports such as the Forestry Statistics Year Book by Korea Forest Service, forest product import and export statistics, and timber use survey and various publically announced statistical data such as the trade statistics and plywood and 
board statistics of Korea Wood Panel Association were mainly used to analyze the trend and characteristics of timber supply and demand in Korea.

For the trend and characteristics of timber supply and demand, the timber was divided into the category of log which is the raw material for wood product and the category of wood product to analyze the production, import, and export of each product. For wood product, the analysis focused on sawn wood, plywood, PB, MDF, and other products (paper, paperboard, and pulp). To help the understanding of readers, this study briefly examined the timber supply and demand trend including self-sufficiency for timber first and probed into the supply and demand relation of each wood product later.

\section{RESULTS AND DISCUSSIONS}

\section{Overview of Timber Supply and Demand}

Timber supply and demand in Korea increased heavily from 13.73 million $\mathrm{m}^{3}$ in 1980 up to 21.74 million $\mathrm{m}^{3}$ in 1990, and 27.4 million $\mathrm{m}^{3}$ in 1996 . However, due to the financial crisis that started at the end of 1997, the figure temporarily went down to 26.45 million $\mathrm{m}^{3}$ in 1997 and 20.08 million $\mathrm{m}^{3}$ in 1998 and bounced back with the economic recovery and recorded the highest figure of 29.04 million $\mathrm{m}^{3}$ in 2002 . Later, the timber supply and demand has been remaining around 27 million $\mathrm{m}^{3}$ (Table 1 ).

The examination of timber supply by domestic and imported timber showed that only 4.5 million $\mathrm{m}^{3}$ was supplied domestically and imports took absolutely large share. Supply of domestic timber remained around 1.1 million $\mathrm{m}^{3}$ as of 1997 , however, increased gradually and reached up to 2.03 million $\mathrm{m}^{3}$ in 2004 and 4.5 million $\mathrm{m}^{3}$ in 2012. The ratio of domestic timber (self-sufficiency rate) in total supply was only 4 5\% before 1998, however, increased with the increase of domestic timber supply up to $5.7 \%$ in $2000,8.8 \%$ in $2005,13.5 \%$ in 2010 , and $16.2 \%$ in 2012 , the highest figure in history. Although the self-sufficiency rate increased with the increase of domestic timber production due to the effort to develop forest resources, most of the supply is composed of smalldiameter logs and the industrial usage is low (Korea Forest Service, 2013a).

The imports recorded 20.6 million $\mathrm{m}^{3}$ in 199024.27 million $\mathrm{m}^{3}$ in 1995, and 27.44 million $\mathrm{m}^{3}$ in 2002 which was the highest in history. Later, the imports decreased along with the decrease of import logs down to 23.89 million $\mathrm{m}^{3}$ in 2010 and 23.31 million $\mathrm{m}^{3}$ in 2012. When divided into log and wood product, the log accounted for $40 \%$ and wood product, $60 \%$ in 1990 , respectively. The ratio of wood product increased gradually later and reached $74 \%$ in 2000 and $80 \%$ as of 2010. As of 2012, Log accounts for $16 \%$ of imports and wood products, $84 \%$.

Meanwhile, the log demand of domestic wood industry gradually decreased from 1991 when it reached the peak, 10.14 million, and recorded 8.32 million $\mathrm{m}^{3}$ in 2000 , 7.94 million $\mathrm{m}^{3}$ in 2010 , and 8.19 million $\mathrm{m}^{3}$ in 2012. This is attributed to the timber supply structure switching to

Table 1. Trends of Timber Supply and Demand

(Unit: $1,000 \mathrm{~m}^{3}$ )

\begin{tabular}{|c|c|c|c|c|c|c|c|}
\hline \multirow{2}{*}{ Year } & \multirow{2}{*}{ Total } & \multicolumn{3}{|c|}{$\log$} & \multirow{2}{*}{$\begin{array}{l}\text { (Waste } \\
\text { Timber) }\end{array}$} & \multirow{2}{*}{ Timber Product Import } & \multirow{2}{*}{$\begin{array}{c}\text { Self-Sufficiency } \\
\text { Rate (\%) }\end{array}$} \\
\hline & & Total & Domestic & Import & & & \\
\hline 1990 & 21,746 & 9,423 & 1,138 & 8,285 & $(640)$ & 12,323 & 5.2 \\
\hline 1995 & 25,325 & 9,284 & 1,055 & 8,229 & $(1,454)$ & 16,041 & 4.2 \\
\hline 1996 & 27,404 & 9,225 & 1,195 & 8,030 & $(1,602)$ & 18,179 & 4.4 \\
\hline 1997 & 26,452 & 9,328 & 1,062 & 8,266 & $(1,723)$ & 17,124 & 4.0 \\
\hline 1998 & 20,081 & 5,798 & 1,428 & 4,370 & $(1,185)$ & 14,283 & 7.1 \\
\hline 1999 & 27,816 & 8,317 & 1,694 & 6,623 & $(1,582)$ & 19,499 & 6.0 \\
\hline 2000 & 27,970 & 8,327 & 1,592 & 6,735 & $(1,816)$ & 19,643 & 5.7 \\
\hline 2001 & 26,243 & 8,836 & 1,533 & 7,303 & $(1,905)$ & 17,407 & 5.9 \\
\hline 2002 & 29,047 & 9,312 & 1,605 & 7,707 & $(1,873)$ & 19,735 & 5.5 \\
\hline 2003 & 27,389 & 8,727 & 1,740 & 6,987 & $(2,275)$ & 18,662 & 6.4 \\
\hline 2004 & 27,211 & 8,619 & 2,037 & 6,582 & $(2,220)$ & 18,592 & 7.5 \\
\hline 2005 & 26,719 & 8,372 & 2,350 & 6,022 & $(2,258)$ & 18,347 & 8.8 \\
\hline 2006 & 26,623 & 8,809 & 2,444 & 6,365 & $(2,347)$ & 17,814 & 9.2 \\
\hline 2007 & 27,347 & 9,013 & 2,680 & 6,333 & $(2,699)$ & 18,334 & 9.8 \\
\hline 2008 & 26,752 & 7,969 & 2,702 & 5,267 & $(2,700)$ & 18,783 & 10.1 \\
\hline 2009 & 26,607 & 8,190 & 3,176 & 5,014 & $(2,181)$ & 18,417 & 11.9 \\
\hline 2010 & 27,612 & 7,942 & 3,715 & 4,227 & $(2,228)$ & 19,670 & 13.5 \\
\hline 2011 & 27,608 & 8,240 & 4,210 & 4,030 & $(2,198)$ & 19,368 & 15.2 \\
\hline 2012 & 27,819 & 8,192 & 4,506 & 3,686 & $(2,131)$ & 19,627 & 16.2 \\
\hline
\end{tabular}

Note: ( ) is not included in the total

Source: Korea Forest Service. 2013 Statistical Yearbook of Forestry 
the importation of wood products.

The examination of the log demand by usage showed that the pulp wood accounted for the larges share, $49.2 \%$, of the total demand, 8.19 million $\mathrm{m}^{3}$ as of 2012 followed by general wood including sawn wood (45.7\%), plywood (4.9\%), and mine timber $(0.2 \%)$. The one that accounted for the largest ratio of the log demand in the 1970's and at the beginning of the 1980's was plywood. However, domestic plywood industry rapidly lost competitiveness along with the increase of plywood import, and the log demand for plywood decreased down to 1.84 million $\mathrm{m}^{3}$ and accounted for $19.6 \%$ of total demand in 1990, 1.29 million $\mathrm{m}^{3}$ and $12.8 \%$ in 2000, and the lowest $390,000 \mathrm{~m}^{3}$ and $4.9 \%$ in 2010, quickly losing its importance in the wood industry (Table 2).

The log demand for general wood was 6.28 million $\mathrm{m}^{3}$ in 1990, however, greatly decreased down to 3.30 million $\mathrm{m}^{3}$ in 1998 due to the financial crisis that started at the end of 1997. Later, the demand gradually increased due to economic recovery and reached 5.42 million $\mathrm{m}^{3}$ in 2000 and 7.36 million $\mathrm{m}^{3}$ in 2002, the highest figure in history. However, the demand has been decreasing due to the recess in domestic construction business from the late 2000's.

Pulp wood had only accounted for $5 \%$ of log supply and demand $\left(500,000 \mathrm{~m}^{3}\right)$ until 1990; however, the share increased up to $15.6 \%$ (1.29 million $\mathrm{m}^{3}$ ) as of 2000, and this level was maintained until the late 2000's. The demand for pulp wood increased further in 2010 and the rate reached up to $45.3 \%$ (3.74 million $\mathrm{m}^{3}$ ) as of 2011 and up to $49.2 \%$ (4.02 million $\mathrm{m}^{3}$ ) as of 2012 , the highest rate in history.

The consumption of mine timber increased until the late 1980's along with the increase of coal production. However, the increase of alternative energy such as petroleum and LPG after the 1980's and the coal industry rationalization measures by the government rapidly decreased the number of mines and the consumption of mine timber quickly decreased down to $510,000 \mathrm{~m}^{3}$ as of $1990,110,000 \mathrm{~m}^{3}$ as of 2000 , and $20,000 \mathrm{~m}^{3}$ as of 2012 (Korea Forest Research Institute, 2007).

\section{Trends and Characteristics of Supply and Demand of $\mathbf{L o g}$}

Production

Domestic log production was roughly 1.1 million $\mathrm{m}^{3}$ around 1990. However, it increased gradually from the late 1990's and remained around 1.7 million $\mathrm{m}^{3}$ until 2003. Later, the afforestation project to expand forest sink as a countermeasure for global warming was implemented in full, and log production increased from 2.03 million $\mathrm{m}^{3}$ in 2004 up to 3.71 million $\mathrm{m}^{3}$ in 2010 and 4.51 million $\mathrm{m}^{3}$ in 2012 (four-fold increase compared with 1990), which was the highest figure in history (Korea Forest Service, 2013b).

By usage, the log production for general materials including sawn wood accounted for the largest share (3.45 million $\mathrm{m}^{3}$ ) among 4.50 million $\mathrm{m}^{3}$ as of 2012 followed by that for pulp (1.03 million $\mathrm{m}^{3}$ ) and that for mine timber $\left(20,000 \mathrm{~m}^{3}\right)$. Especially, the general materials

Table 2. Trends of Log Supply and Demand

(Unit: $1,000 \mathrm{~m}^{3}$ )

\begin{tabular}{|c|c|c|c|c|c|c|c|c|c|}
\hline \multirow{2}{*}{ Year } & \multirow{2}{*}{ Total } & \multicolumn{5}{|c|}{ For Domestic Consumption } & \multicolumn{3}{|c|}{ For Export } \\
\hline & & Total & Mine Timber & Pulp & Plywood & Sawn Wood & Total & Plywood & Sawn Wood \\
\hline 1990 & 9,423 & 9,121 & 512 & 479 & 1,849 & 6,281 & 302 & 40 & 262 \\
\hline 1995 & 9,284 & 8,939 & 139 & 1,275 & 1,300 & 6,225 & 345 & 186 & 159 \\
\hline 1996 & 9,225 & 8,893 & 109 & 1,287 & 1,334 & 6,163 & 332 & 159 & 173 \\
\hline 1997 & 9,328 & 8,987 & 104 & 1,253 & 1,611 & 6,019 & 341 & 79 & 262 \\
\hline 1998 & 5,798 & 5,265 & 110 & 992 & 859 & 3,304 & 533 & 262 & 271 \\
\hline 1999 & 8,317 & 7,836 & 117 & 1,361 & 1,051 & 5,307 & 481 & 233 & 248 \\
\hline 2000 & 8,327 & 7,897 & 112 & 1,295 & 1,066 & 5,424 & 430 & 179 & 251 \\
\hline 2001 & 8,836 & 8,665 & 140 & 1,036 & 504 & 6,985 & 171 & 109 & 62 \\
\hline 2002 & 9,312 & 9,207 & 58 & 1,145 & 638 & 7,366 & 105 & 63 & 42 \\
\hline 2003 & 8,727 & 8,622 & 63 & 1,216 & 758 & 6,585 & 105 & 67 & 38 \\
\hline 2004 & 8,619 & 8,473 & 62 & 1,424 & 597 & 6,390 & 146 & 75 & 71 \\
\hline 2005 & 8,372 & 8,313 & 55 & 1,546 & 549 & 6,163 & 59 & 18 & 41 \\
\hline 2006 & 8,809 & 8,740 & 47 & 1,437 & 1,106 & 6,150 & 69 & 23 & 46 \\
\hline 2007 & 9,013 & 9,013 & 45 & 1,643 & 1,110 & 6,215 & - & - & - \\
\hline 2008 & 7,969 & 7,969 & 45 & 1,757 & 618 & 5,549 & - & - & - \\
\hline 2009 & 8,190 & 8,290 & 39 & 1,919 & 500 & 5,732 & - & - & - \\
\hline 2010 & 7,942 & 7,942 & 29 & 2,549 & 393 & 4,971 & - & - & - \\
\hline 2011 & 8,240 & 8,240 & 32 & 3,734 & 450 & 4,024 & - & - & - \\
\hline 2012 & 8,192 & 8,192 & 18 & 4,028 & 406 & 3,740 & - & - & - \\
\hline
\end{tabular}




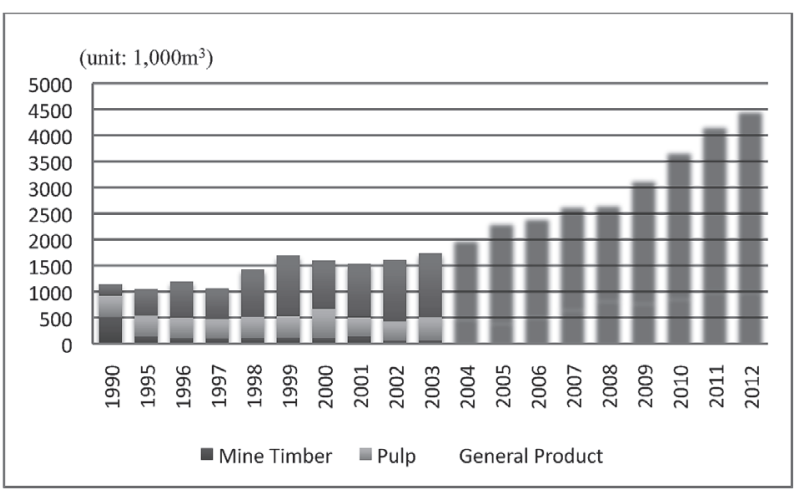

Fig. 1. Trends of Log Production.

Source: Korea Forest Service. 2013 Statistical Yearbook of Forestry

drastically increased up to $220,000 \mathrm{~m}^{3}$ in 1990 centering on conifer, $930,000 \mathrm{~m}^{3}$ in 2000, 27.94 million $\mathrm{m}^{3}$ in 2010, and 3.46 million $\mathrm{m}^{3}$ in 2012 (16-fold increase compared with 1990), which was the highest figure in history (Figue 1).

The permissions issued for domestic timber lumbering showed that the lumbering increased from 229 million $\mathrm{m}^{3}$ in 2008 up to 867 million $\mathrm{m}^{3}$ in 2010 and 1,070 million $\mathrm{m}^{3}$ in 2012 . This is attributed to the increase of the final cutting of domestic forest resources which are becoming rich, thinning by afforestation project, lumbering based on the conversion from a mountainous district, species renewal, and lumbering of damaged trees. The lumbering as of 2012 recorded 1,070 million $\mathrm{m}^{3}$, and the thinning accounted for 710 million $\mathrm{m}^{3}$ followed by final cutting (118 million $\mathrm{m}^{3}$ ), species renewal $\left(102\right.$ million $\left.\mathrm{m}^{3}\right)$, and damaged trees $\left(360,000 \mathrm{~m}^{3}\right)$, respectively (Table 3).

\section{Import}

Log imports continued to decrease from 6.73 million $\mathrm{m}^{3}$ in 2000 down to 6.22 million $\mathrm{m}^{3}$ in 2005 , and 4.22 million $\mathrm{m}^{3}$ in 2010, and recorded the lowest figure of 3.68 million $\mathrm{m}^{3}$ in 2012 (33\% lower than 2000). By country, the import of New Zealand (2.56 million $\mathrm{m}^{3}$ )accounted for the largest share of total log import in 2013 followed by America ( 0.39 million $\left.\mathrm{m}^{3}\right)$, Canada $\left(0.28\right.$ million $\left.\mathrm{m}^{3}\right)$, Australia (0.17 million $\left.\mathrm{m}^{3}\right)$, Russia (0.09 million $\left.\mathrm{m}^{3}\right)$, and PNG $\left(0.08\right.$ million $\left.\mathrm{m}^{3}\right)$, respectively.

New Zealand holds an important status for the import of log in Korea. However, the import decreased

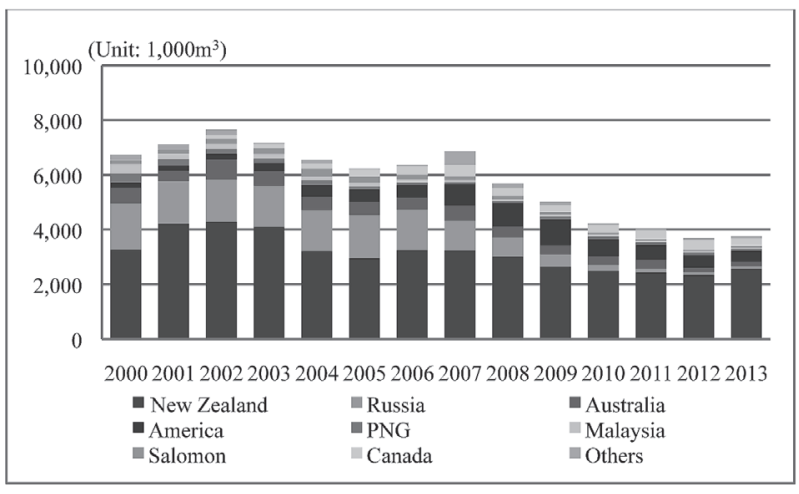

Fig. 2. Trends of Log Import.

Source: Korea Forest Service. 2013 Forest Product Import/Export Statistics

from the 2000's from 3.23 million $\mathrm{m}^{3}$ in 2007 and drastically down to 2.34 million $\mathrm{m}^{3}$ in 2012 . The import from Russia also decreased from 1.68 million $\mathrm{m}^{3}$ in 2000 down to 0.70 million $\mathrm{m}^{3}$ in 2008, and 0.10 million $\mathrm{m}^{3}$ in 2012 . Contrary to the decrease of log import from New Zealand and Russia, the import from America, Canada, and Australia has steadily increased from the early 2000's although the quantity is small. The import from Japan also increased greatly from $1,000 \mathrm{~m}^{3}$ in 2000 up to $7,000 \mathrm{~m}^{3}$ in 2007, and 43,000 $\mathrm{m}^{3}$ in 2013 (Figue 2).

On the other hand, the examination of log imports by their species showed that the import of New Zealand's Radiatapine which is used as temporary construction materials and low-end goods as of 2010 took the absolutely large share (2,100.7 million tons) of imports followed by North American Hemlock (427.8 million tons) and Douglas fir (114.0 million tons), and Russian Spruce (0.94 million tons) and Larch (88.6 million tons). Particularly, Russian Larch showed rapid decrease from 661.6 million tons in 2007 down to 163.7 million tons in 2010, and 88.6 million tons in 2012 (7.5 fold decrease from 2007). Spruce decreased sharply from 356.3 million tons in 2007 down to 102.4 million tons in 2010 and 94.6 million tons in 2012. North American Douglas fir showed consistent decrease for overall species while the import maintains similar trend as the past without much changes (Table 4).

A variety of species of hardwood are imported from around the world. Regarding species that have been imported as of 2012, Meranti accounts for the largest

Table 3. Volume of Permissions Issued for Lumbering of Domestic

\begin{tabular}{ccccccc}
\hline Year & Total & Final Cutting & Thinning & Species Renewal & Damaged Tree & Other \\
\hline 2008 & 2,288 & 795 & 740 & 522 & 36 & 195 \\
2009 & 3,720 & 1,027 & 1,143 & 687 & 84 & 579 \\
2010 & 8,671 & 1,136 & 5,858 & 736 & 453 & 488 \\
2011 & 9,953 & 1,272 & 6,863 & 871 & 322 & 625 \\
2012 & 10,700 & 1,183 & 7,100 & 1,022 & 356 & 1,039
\end{tabular}

Source: Korea Forest Service. 2013 Statistical Yearbook of Forestry 
Table 4. Trends of Conifer Log Import by Species

\begin{tabular}{cccccccr}
\hline Year & Cedar & Douglas fir & Hemlock & Redpine & Larch & Spruce & Radiatapine \\
\hline 2007 & 22,000 & 114,867 & 701,723 & 115,010 & 661,676 & 356,344 & $3,184,330$ \\
2008 & 33,737 & 142,255 & 623,386 & 51,996 & 455,050 & 284,787 & $2,845,967$ \\
2009 & 25,696 & 179,574 & 708,440 & 15,253 & 352,945 & 171,721 & $2,465,411$ \\
2010 & 15,802 & 148,229 & 514,552 & 4,605 & 163,798 & 102,402 & $2,338,746$ \\
2011 & 12,923 & 137,790 & 466,881 & 9,147 & 84,869 & 102,951 & $2,327,590$ \\
2012 & 11,881 & 114,047 & 427,850 & 6,104 & 88,698 & 94,657 & $2,100,788$ \\
\hline
\end{tabular}

Source: Korea Foreign Trade Association. 2013 Trade Statistics, Import/Export by Item (HSK 440300000)

portion (5.33 million tons) followed by Oak (4.14 million tons), Keruing (3.73 million tons), Maple (2.75 million tons), Ash (2.62 million tons), and Walnut (1.60 million tons), respectively. Particularly, the import of Meranti decreased from 12.72 million tons in 2007 down to 1.60 million tons in 2012, and Beech also decreased from 1.05 million tons in 2007 down to 0.40 million tons in 2012. Keruing, Oak, and so forth showed minor increase (Table 5).

\section{Trends and Characteristics of Sawn Wood Supply and Demand}

Sawn wood is produced by using conifer and hardwood. In Korea, the conifer sawn wood is mostly used as construction materials and hardwood sawn wood, as the material for manufacturing furniture, floor covering, wood craft, cabinet, storage box, pallet, and container and also various industrial materials. The demand for hardwood sawn wood is small while mostly conifer sawn wood is used.

In Korea, the statistics about sawn wood had been included in the Forest Statistics Year Book published by Korea Forest Service until 1996. However, nationwide survey on sawmill industry had not been conducted after
1996 and the time series statistical data on sawn wood production are not developed. Later, Korea Forest Service has conducted Survey on Timber Use regarding sawmill industries of Korea from 2007 and provided the statistics on the production of sawn wood and sawmill industry (Korea Forest Service, 2012).

According to 2011 Survey on Timber Use conducted by the Korea Forest Service in 2012, the production of sawn wood decreased sharply from 3.01 million $\mathrm{m}^{3}$ in down to 2.02 million $\mathrm{m}^{3}$ in 2010 , and 1.91 million $\mathrm{m}^{3}$ in 2011 (1.6 fold decrease from 2008). By raw materials or by domestic log product and imported log product, the production of sawn wood, 0.24 million $\mathrm{m}^{3}$ of the total production as of 2011 (1.91 million $\mathrm{m}^{3}$ ) was the domestic log and 1.66 million $\mathrm{m}^{3}$, the imported log; the production of sawn wood depended heavily on imports (Table 6).

The timber supply and demand structure in Korea depends on imports for most of wood supply and the imports accounts for an absolutely large portion of timber supply. For this, very few amount of sawn wood is exported and the supply of timber mostly depends on imports. The import of sawn wood has increased consistently contrary to the decrease of log import. The import of sawn wood showed great increase from $739,000 \mathrm{~m}^{3}$ in

Table 5. Trends of Hardwood Log Import by Species

\begin{tabular}{|c|c|c|c|c|c|c|c|c|}
\hline Year & Meranti & Teak & Keruing & Jerutong & Okoume & Mahogany & Oak & Beech \\
\hline 2007 & 12,727 & 247 & 3,070 & 1,021 & 1,131 & 1,991 & 3,992 & 1,058 \\
\hline 2008 & 5,413 & 261 & 25,36 & 1,081 & 1,104 & 29 & 5,911 & 627 \\
\hline 2009 & 3,363 & 268 & 3,955 & 970 & 1,056 & 348 & 3,001 & 656 \\
\hline 2010 & 3,435 & 300 & 3,086 & 890 & 262 & 654 & 4,367 & 253 \\
\hline 2011 & 8,384 & 328 & 3,056 & 576 & 472 & 1,758 & 3,835 & 399 \\
\hline 2012 & 5,333 & 87 & 3,733 & 575 & 519 & 1,005 & 4,140 & 405 \\
\hline Year & Rosewood & Ebony & Ash & Walnut & Poplar & Maple & Birch & Basswood \\
\hline 2007 & 0 & 54 & 4,234 & 5,709 & 3,477 & 4,622 & 123 & 300 \\
\hline 2008 & 18 & 47 & 2,776 & 3,903 & 2,715 & 3,370 & 205 & 147 \\
\hline 2009 & 27 & 51 & 2,237 & 4,088 & 8,391 & 3,888 & 282 & 1 \\
\hline 2010 & 1 & 27 & 3,905 & 3,036 & 454 & 3,947 & 787 & 211 \\
\hline 2011 & 68 & 21 & 2,481 & 1,852 & 701 & 2,773 & 128 & 172 \\
\hline 2012 & 29 & - & 2,622 & 1,600 & 1,316 & 2,754 & 183 & 47 \\
\hline
\end{tabular}

Source: Korea Foreign Trade Association. 2013 Trade Statistics, Import/Export by Item (HSK 440300000) 
Table 6. Trends of Sawn Wood Production

\begin{tabular}{cccc}
\hline Year & Total & $\begin{array}{c}\text { Domestic Log } \\
\text { Product }\end{array}$ & $\begin{array}{c}\text { Imported Log } \\
\text { Product }\end{array}$ \\
\hline 2008 & $3,013,545$ & 450,744 & $2,562,801$ \\
2009 & $2,399,720$ & 273,065 & $2,126,655$ \\
2010 & $2,023,525$ & 268,233 & $1,710,776$ \\
2011 & $1,916,689$ & 242,362 & $1,674,325$ \\
\hline
\end{tabular}

Source: Korea Forest Service. 2013 Survey on Timber Use

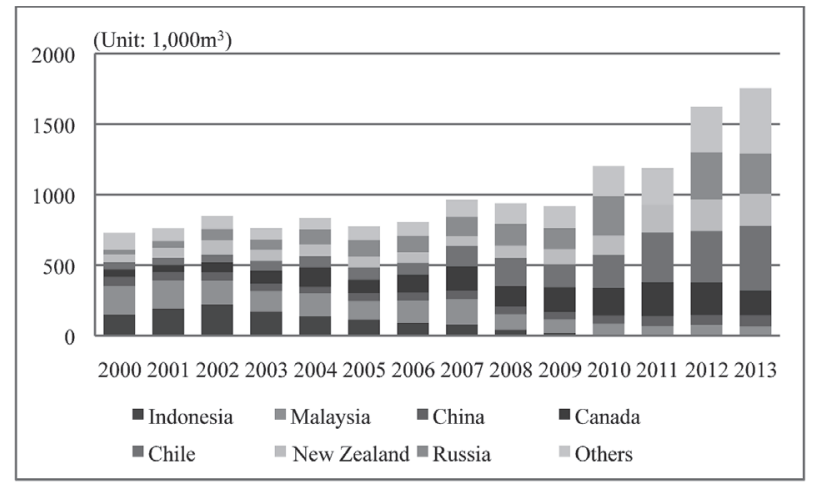

Fig. 3. Trends of Sawn Timber Import.

Source: Korea Forest Service. 2013 Forest Product Import/Export Statistics
2000 up to $806,000 \mathrm{~m}^{3}$ in 2006 , and $1,756,000 \mathrm{~m}^{3}$ in 2013 (2.4 fold increase compared with 2000).

By country, the largest quantity of sawn wood was imported from Chile as of $2013,458,000 \mathrm{~m}^{3}$ out of the total $1,756,000 \mathrm{~m}^{3}$, followed by Russia $\left(285,000 \mathrm{~m}^{3}\right)$, Canada $\left(174,000 \mathrm{~m}^{3}\right)$, New Zealand $\left(227,000 \mathrm{~m}^{3}\right)$, and Malaysia $\left(63,000 \mathrm{~m}^{3}\right)$. From the 2000's, the imports from Southeast Asian countries such as Indonesia and Malaysia decreased continuously while the imports from Canada, Chile, New Zealand, and Russia that are used for construction are increasing noticeably. Particularly, the increase of imports from Russia and Chile is conspicuous. The import from Russia increased greatly from $34,000 \mathrm{~m}^{3}$ in 2000 up to $277,000 \mathrm{~m}^{3}$ in 2010 , and $335,000 \mathrm{~m}^{3}$ in 2012 (9.8 fold increase compared with 2000). The import from Chile also increased greatly from $52,000 \mathrm{~m}^{3}$ in 2000 up to $230,000 \mathrm{~m}^{3}$ in 2010, and 364,000 $\mathrm{m}^{3} 2012$ (7-fold increase compared with 2000) (Figue 3).

\section{Trends and Characteristics of Timber Board Supply and Demand}

Production

Korean plywood lost its competitive strength in the overseas market after Southeast Asian countries including Indonesia and Malaysia limited log export to protect their forest resources from the late 1980's and began to promote plywood industry and expand export, resulting in the decrease of domestic production. Plywood production decreased from $1,124,000 \mathrm{~m}^{3}$ in 1990 down to $747,000 \mathrm{~m}^{3}$ in $2000,450,000 \mathrm{~m}^{3}$ in 2010 , and $435,000 \mathrm{~m}^{3}$

Table 7. Trends of Timber Board Production

(Unit: $\mathrm{m}^{3}$ )

\begin{tabular}{|c|c|c|c|c|c|c|}
\hline \multirow{2}{*}{ Year } & \multicolumn{2}{|c|}{ Plywood } & \multicolumn{2}{|c|}{$\mathrm{PB}$} & \multicolumn{2}{|c|}{ MDF } \\
\hline & Production & Domestic Supply & Production & Domestic Supply & Production & Domestic Supply \\
\hline 1990 & $1,123,625$ & $1,011,179$ & 165,103 & 165,103 & 113,163 & 113,163 \\
\hline 1995 & 974,237 & 974,237 & 548,195 & 547,180 & 590,087 & 542,904 \\
\hline 1996 & 895,979 & 895,979 & 659,417 & 641,396 & 719,741 & 630,730 \\
\hline 1997 & $1,014,054$ & $1,014,054$ & 720,735 & 747,793 & 728,184 & 688,690 \\
\hline 1998 & 640,967 & 640,967 & 507,157 & 505,543 & 570,613 & 506,541 \\
\hline 1999 & 733,680 & 733,680 & 672,469 & 657,776 & 831,254 & 745,074 \\
\hline 2000 & 747,248 & 747,248 & 722,426 & 717,981 & 931,127 & 783,181 \\
\hline 2001 & 736,066 & 736,066 & 723,029 & 731,678 & $1,009,466$ & 996,050 \\
\hline 2002 & 824,124 & 824,124 & 728,139 & 670,526 & $1,229,475$ & $1,149,128$ \\
\hline 2003 & 833,693 & 833,693 & 794,206 & 868,234 & $1,318,205$ & $1,274,664$ \\
\hline 2004 & 698,772 & 698,772 & 896,482 & 845,002 & $1,584,224$ & $1,498,345$ \\
\hline 2005 & 680,168 & 680,168 & 847,367 & 872,516 & $1,653,016$ & $1,579,905$ \\
\hline 2006 & 741,172 & 741,172 & 776,943 & 755,590 & $1,641,743$ & $1,631,509$ \\
\hline 2007 & 763,902 & 763,902 & 955,045 & 958,111 & $1,716,833$ & $1,743,537$ \\
\hline 2008 & 666,925 & 666,925 & 950,375 & 947,652 & $1,690,318$ & $1,597,009$ \\
\hline 2009 & 493,123 & 493,123 & 933,587 & 945,956 & $1,655,225$ & $1,696,083$ \\
\hline 2010 & 450,080 & 450,080 & 918,943 & 899,048 & $1,836,076$ & $1,751,271$ \\
\hline 2011 & 455,101 & 455,101 & 794,865 & 816,917 & $1,812,458$ & $1,745,628$ \\
\hline 2012 & 434,623 & 434,623 & 800,988 & 772,266 & $1,712,313$ & $1,593,119$ \\
\hline
\end{tabular}

Source: Korea Forest Service. 2013 Statistical Yearbook of Forestry 
in 2012 (2.6 fold decrease from 1990) (Table 7).

By the type of plywood, regular plywood and processed plywood, the regular plywood accounted for $78.4 \%$ $\left(341,000 \mathrm{~m}^{3}\right)$ of the total domestic production as of 2012 $\left(434,000 \mathrm{~m}^{3}\right)$ and processed plywood, 21.6\% $\left(94,000 \mathrm{~m}^{3}\right)$ (Table 8). By thickness, $6 \mathrm{~mm}$ or thinner regular plywood which is used for furniture and interior materials until the 1970's accounted for the most part of regular plywood production. However, the production of $12 \mathrm{~mm}$ or thicker regular plywood which is for concrete mold began to increase from 1990. As of 2012, $12 \mathrm{~mm}$ or thicker plywood accounted for the largest share (71.9\%) followed by $6.0-11.9 \mathrm{~mm}$ plywood (26.1\%), and $6 \mathrm{~mm}$ or thinner plywood $(2.1 \%)$, respectively. The change in production by thickness is attributed to Korea's loss of competitiveness for $6 \mathrm{~mm}$ or thinner plywood due to high productivity of Southeast Asian countries. On the contrary, domestic products have competitive edge for $12 \mathrm{~mm}$ or thicker plywood compared with the low productivity of Southeast Asian countries for the type of plywood (Table 9).

Boards are divided into particle board (PB) and medium-density fiberboard (MDF), and they have made great progresses as the alternative for plywood from the 1990 's. PB is mainly applied to kitchen furniture, office furniture, sound system case, general furniture, construction materials, and housing facilities. MDF is also applied to general furniture, office furniture construction material, floor covering, sound system case, and instrument (Korea Timber Panel Association, 2013).

$\mathrm{PB}$ production increased from 165,000 $\mathrm{m}^{3}$ in 1990 up to $718,000 \mathrm{~m}^{3}$ in 2000 , and $801,000 \mathrm{~m}^{3}$ in 2012 . MDF production also increased noticeably from $113,000 \mathrm{~m}^{3}$ in 1990 up to $931,000 \mathrm{~m}^{3}$ in 2000 , and $1,712,000 \mathrm{~m}^{3}$ in 2012 . This is contrary to the downturn of plywood following the peak in the 1980's. According to the production of plywood compared with boards ( $\mathrm{PB}+\mathrm{MDF})$, the plywood production in 1990 was $1,124,000 \mathrm{~m}^{3}$ and the board production, $278,000 \mathrm{~m}^{3}$, and the boards only accounted for $20 \%$. However, the production of boards increased rapidly from the end of 1990's and reached up to 1,654,000 $\mathrm{m}^{3}$ in 2000 with the share of $69 \%$. It continued to increase and reached $2,513,000 \mathrm{~m}^{3}$ in 2012 with the share of $85 \%$. Especially, the share of MDF was only $8 \%$ in 1990, however, increased up to 39\% in 2000 and 57\% in 2012. This

Table 8. Trends of Plywood Production

\begin{tabular}{|c|c|c|c|}
\hline Year & Total & Regular Plywood & Processed Plywood \\
\hline 2003 & 833,693 & 665,095 & 168,598 \\
\hline 2004 & 698,772 & 561,287 & 137,485 \\
\hline 2005 & 634,630 & 513,333 & 121,297 \\
\hline 2006 & 673,815 & 540,306 & 133,509 \\
\hline 2007 & 698,743 & 615,410 & 83,333 \\
\hline 2008 & 598,635 & 535,688 & 62,947 \\
\hline 2009 & 438,859 & 379,675 & 59,184 \\
\hline 2010 & 391,853 & 344,239 & 47,614 \\
\hline 2011 & 405,268 & 364,102 & 41,166 \\
\hline 2012 & 434,623 & 340,746 & 93,877 \\
\hline
\end{tabular}

Note: This table represents the plywood production by the members of Korea Timber Panel Association. Source: Korea Timber Panel Association. 2013 Plywood and Board Statistics

Table 9. Trends of Regular Plywood Production by Thickness

(Unit: $\mathrm{m}^{3}$ )

\begin{tabular}{|c|c|c|c|c|c|}
\hline Year & Total & $3.5 \mathrm{~mm}$ or Less & $3.6-5.9 \mathrm{~mm}$ & $6.0-11.9 \mathrm{~mm}$ & 12.0mm or Thicker \\
\hline 2003 & 665,095 & 32 & 6,343 & 36,218 & 622,502 \\
\hline 2004 & 561,287 & 7 & 5,035 & 47,556 & 508,689 \\
\hline 2005 & 513,333 & 69 & 5,441 & 51,454 & 456,369 \\
\hline 2006 & 540,306 & 30 & 7,698 & 66,930 & 465,648 \\
\hline 2007 & 615,410 & - & 9,138 & 90,257 & 516,015 \\
\hline 2008 & 535,688 & - & 7,732 & 77,516 & 450,440 \\
\hline 2009 & 379,675 & - & 9,000 & 47,120 & 323,555 \\
\hline 2010 & 344,239 & - & 9,647 & 55,289 & 279,303 \\
\hline 2011 & 364,102 & - & 11,261 & 51,804 & 301,037 \\
\hline 2012 & 340,746 & - & 7,017 & 88,858 & 244,871 \\
\hline
\end{tabular}

Note: This table represents the plywood production by the members of Korea Timber Panel Association.

Source: Korea Timber Panel Association. 2013 Plywood and Board Statistics 
is attributed to the increase of repair and remodeling of old buildings from the 2000's and the continuous increase of construction demand such as pension.

\section{Import}

The import of plywood was close to zero until the 1980 's, however, has continuously increased from the late 1990 's. The quantity has remained around 1200,000 $\mathrm{m}^{3}$ in the 2000's without much changes for the import is increasing in the form of replacing the decrease in domestic production. Plywood import in 2013 was 1,287,000 m³, and the largest volume $\left(610,000 \mathrm{~m}^{3}\right)$ was imported from China followed by Malaysia $\left(358,000 \mathrm{~m}^{3}\right)$, Indonesia $\left(115,000 \mathrm{~m}^{3}\right)$, and Finland $\left(47,000 \mathrm{~m}^{3}\right)$, respectively. The import of plywood from China increased noticeably from the 2000's contrary to the decrease in import from Southeast Asia (Figue 4).

The import of PB increased from $485,000 \mathrm{~m}^{3}$ in 2000 up to $759,000 \mathrm{~m}^{3}$ in 2005 and $955,000 \mathrm{~m}^{3}$ in 2006 , which was the highest in history. However, the figure took the downturn afterwards and recorded 857,000 $\mathrm{m}^{3}$ in 2013. $\mathrm{PB}$ is mainly imported from Thailand and Rumania. Especially, the import from Thailand increased from $144,000 \mathrm{~m}^{3}$ in 2000 up to $690,000 \mathrm{~m}^{3}$ in 2006 (4.8 fold increase from 2000), which was the highest in history.

The import of MDF recorded 753,000 $\mathrm{m}^{3}$ in 2002 and turned to declining path afterwards, and it recorded $266,000 \mathrm{~m}^{3}$ in 2010 and further decreased down to $130,000 \mathrm{~m}^{3}$ in 2013. Most MDF is imported from China, and the import which was only $8,000 \mathrm{~m}^{3}$ in 2008 grew up to $237,000 \mathrm{~m}^{3}$ in 2007 , which was the highest figure in history. On the contrary, the import from Australia radically increased from $124,000 \mathrm{~m}^{3}$ in 2001 up to $78,000 \mathrm{~m}^{3}$ in 2005 and $2,000 \mathrm{~m}^{3}$ in 2013.

\section{Export}

Most plywood produced in Korea was exported until the 1970's. However, the export decreased rapidly as Korean plywood lost competitiveness in the overseas market and the domestic demand increased from the 1990 's. The export of plywood decreased from $118,000 \mathrm{~m}^{3}$ in 2000 down to $115,000 \mathrm{~m}^{3}$ in 2005 , and $6,000 \mathrm{~m}^{3}$ in 2013 (Figue 5).

The export of $\mathrm{PB}$ also has its focus on domestic supply. $95.0 \%$ of PB production is spent through domestic supply and only few of them are exported, mainly to Japan. $70.7 \%$ of the total amount of export in 2013 which is $4,000 \mathrm{~m}^{3}$ was exported to Japan.

MDF also concentrates on domestic supply than export. $90.1 \%$ of MDF produced is supplied domestically and only about $5.2 \%$ is exported. MDF export decreased greatly from $99,000 \mathrm{~m}^{3}$ in 2000 down to $48,000 \mathrm{~m}^{3}$ in 2005 , and $20,000 \mathrm{~m}^{3}$ in 2012 . Later on, the export took an increasing trend and recorded the highest figure in history, $105,000 \mathrm{~m}^{3}$, in 2012 . This is attributed to the rapid increase of export to the Middle East to which nearly no export was made before 2010. In addition, the export to Japan still remains significant in quantity.

\section{Trends of Supply and Demand Othter Timbers} Paper and Paterboard

The production of paper and paperboard noticeably

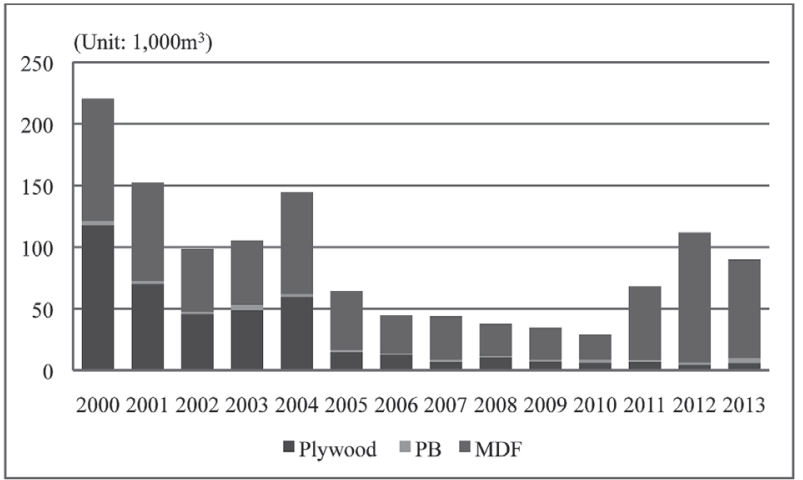

Fig. 5. Trends of Timber Board Export. Source: Korea Forest Service. 2013 Forest Product Import/Export Statistics Source: Korea Forest
Import/Export Statistics

2013 Forest Product

Fig. 4. Trends of Timber Boards Import

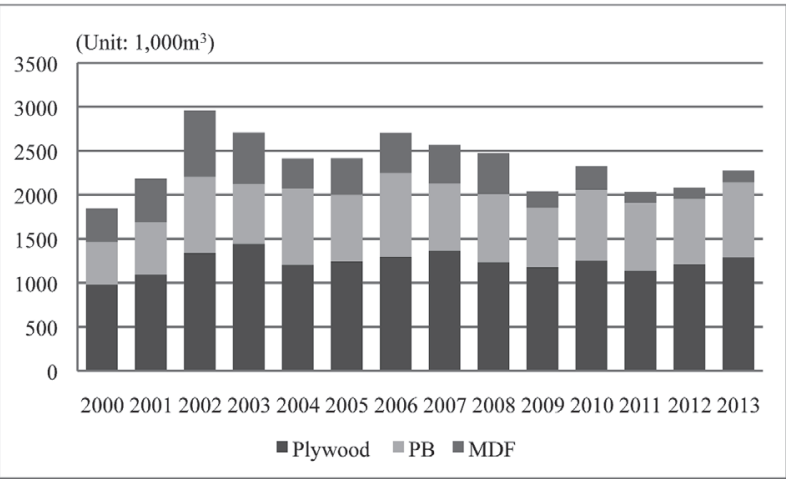

Table 10. Trends of Paper and Paperboard Production

\begin{tabular}{ccccccc}
\hline Year & Total & Newsprint Paper & Printing Paper & Wrapping Paper & Paperboard & Other \\
\hline 2008 & $10,642,495$ & $1,561,652$ & $3,094,409$ & 219,942 & $5,166,021$ & 600,471 \\
2009 & $10,480,673$ & $1,464,229$ & $2,976,980$ & 217,659 & $5,219,247$ & 602,558 \\
2010 & $11,105,835$ & $1,556,101$ & $3,029,585$ & 220,368 & $6,644,422$ & $5,817,538$ \\
2011 & $11,480,372$ & $1,537,479$ & $3,278,415$ & 223,436 & 622,359 \\
2012 & $11,331,970$ & $1,523,288$ & $3,207,348$ & 190,442 & $6,769,479$ \\
\hline
\end{tabular}


increased from the 1990's and reached 5.10 millio tons in 1990, 10.24 million tons in 2000, and 11.33 million tons in 2012. The examination of the production of paper and paperboard by products showed that the paperboard accounted for the largest share, 5.76 million tons in 2012 followed by printing paper (3.20 million tons), newsprint paper (1.52 million tons), and wrapping paper (0.19 million tons) (Table 10).

The import of paper and paperboard was 858,000 tons as of 2012, and the paperboard accounted for the largest share, 311,000 tons, followed by printing paper (210,000 tons), and wrapping paper (52,000 tons) (Table 11). The export increased rapidly from the 2000's and reached 2697,000 tons in 2008, 2995,000 tons in 2010, and 3145,000 tons in 2012 . The printing paper accounted for the largest share, 1,296,000 tons, followed by paperboard (1,033,000 tons), and newsprint paper (702,000 tons) (Table 12).

Pulp

Pulp production remained around 600,000 tons or less in the 2000's without noticeable changes in quantity. The total pulp production as of 2012 was 562,000 tons, and it included 450,000 tons of chemical pulp and 112,000 tons of mechanical pulp. While pulp import has remained around 2,500,000 tons, the import is absolutely

Table 11. Trends of Paper and Paperboard Import

(Unit: ton)

\begin{tabular}{cccccc}
\hline Year & Total & Newsprint Paper & Printing Paper & Wrapping Paper & Paperboard \\
\hline 2008 & 816,871 & 4,338 & 224,488 & 49,355 & 261,467 \\
2009 & 714,472 & 1,557 & 205,485 & 45,593 & 227,223 \\
2010 & 898,643 & 1,932 & 258,412 & 49,884 & 222,160 \\
2011 & 871,305 & 585 & 211,323 & 49,472 & 321,036 \\
2012 & 858,396 & 92 & 210,430 & 51,891 & 319,482 \\
\hline
\end{tabular}

Source: Korea Paper Manufacturers' Association. 2013 Paper Supply and Demand Statistics

Table 12. Trends of Paper and Paperboard Export

\begin{tabular}{ccccccc}
\hline Year & Total & Newsprint Paper & Printing Paper & Wrapping Paper & Paperboard & Other \\
\hline 2008 & $2,696,509$ & 582,527 & $1,072,465$ & 21,173 & 959,972 \\
2009 & $2,889,560$ & 661,336 & $1,074,348$ & 24,186 & $1,070,429$ & 59,372 \\
2010 & $2,829,937$ & 688,010 & $1,017,192$ & 22,482 & $1,021,979$ & 926,035 \\
2011 & $2,994,848$ & 685,043 & $1,275,647$ & 24,668 & 80,274 \\
2012 & $3,144,589$ & 702,217 & $1,296,007$ & 23,255 & 93,455 \\
\hline
\end{tabular}

Source: Korea Paper Manufacturers' Association. 2013 Paper Supply and Demand Statistics

Table 13. Trends of Pulp Supply and Demand

\begin{tabular}{|c|c|c|c|c|c|}
\hline \multirow{2}{*}{ Year } & \multicolumn{3}{|c|}{ Production } & \multirow{2}{*}{ Export } & \multirow{2}{*}{ Import } \\
\hline & Total & Chemical Pulp & Mechanical Pulp & & \\
\hline 2000 & 594 & 419 & 175 & - & 2,166 \\
\hline 2001 & 554 & 427 & 127 & - & 2,319 \\
\hline 2002 & 534 & 419 & 115 & - & 2,532 \\
\hline 2003 & 523 & 415 & 108 & - & 2,455 \\
\hline 2004 & 545 & 427 & 118 & - & 2,568 \\
\hline 2005 & 512 & 411 & 101 & - & 2,087 \\
\hline 2006 & 516 & 426 & 90 & - & 2,422 \\
\hline 2007 & 418 & 338 & 80 & - & 1,728 \\
\hline 2008 & 536 & 425 & 111 & - & 2,482 \\
\hline 2009 & 467 & 361 & 106 & 83 & 2,389 \\
\hline 2010 & 511 & 402 & 109 & 82 & 2,545 \\
\hline 2011 & 585 & 447 & 138 & 26 & 2,538 \\
\hline 2012 & 562 & 450 & 112 & 4 & 2,385 \\
\hline
\end{tabular}

Source: Korea Forest Service. 2013 Statistical Yearbook of Forestry 
greater than the production. The ratio of imports in the supply and demand of pulp is $82.8 \%$ as of 2012. Pulp export is quite small compared with the import (Table 13).

\section{CONCLUSION}

Timber consumption in Korea reached around 27 million $\mathrm{m}^{3}$ a year while the self-sufficiency rate for timber is only $16.2 \%$ as of 2012 . Korea had to depend on imports for the timber supply as its economic development started after the forest resources were devastated by the Korean War. Recently, the self-sufficiency for timber is gradually increasing; however, most of domestically produced timber is used to produce pulp and lowend goods such as boards.

Although self-sufficiency for timber is influenced by domestic economic conditions and the price of imports, it has steadily increased due to the policy promoting the use of domestic timber and the increase of afforestation projects and species renewal projects which are becoming more advanced. However, the wood produced in Korea is mostly small-diameter logs for forest resource management in Korea focuses on afforestation and species renewal and Korea has to depend on imports for large-diameter logs. The import of log from New Zealand which represents Radiatapine accounts for the largest share, 68\% (as of 2013), of total log imports, however, has gradually decreased in the 2000's while the import from North America has continuously increased. In addition, the log import from Japan centering on cypress and cedar is increasing at a fast rate although the quantity is quite small compared with other exporters as more and more consumers are perceiving Japanese timber as quite effective for health.

Although the import of wood products such as sawn wood has continuously increased contrary to the recent decrease of log imports, the increase is quite small in quantity. Log still takes up a major part of import in the domestic wood processing industry as much as the sawn wood accounts for only 30\% of the logs and sawn wood imported.

Meanwhile, PB and MDF are showing strong competitive relationship with plywood in Korea. Contrary to the fact that Korean plywood industry lost its competitiveness in the overseas market in the 1990's and also lost competitive edge for interior materials to Southeast Asian countries, the domestic production for $\mathrm{PB}$ and $\mathrm{MDF}$ has expanded steadily. The domestic production for PB and MDF and its market has been expanding in the 2000's alongside the economic development and the demand for qualitative enhancement of residential environment which boosted the trend of using wood for interior materials and in living. Especially, the share of MDF in wood board (plywood, $\mathrm{PB}, \mathrm{MDF}$ ) production increased heavily from $8 \%$ in 1990 up to $57 \%$ in 2012 . The MDF market is expected to expand further due to the increase of demand for MDF as the material for furniture and interior.

According to the Comprehensive Plan for Promoting Wood Industry (2012-2016) established by Korea Forest Service in 2011, they set up the goal of increasing the self-sufficiency for timber up to $20 \%$ as of 2016 (Korea Forest Service, 2011). Furthermore, President Keun-hye Park also promised to increase the self-sufficiency for timber up to $21 \%$ as of 2017 through her campaign promise. These plans were devised based on the prospect that the production and supply of domestic timber would increase as domestic forest resources are growing rich. Therefore, the use and application of domestic forest resources will become a new task for timber supply and demand, and necessary actions shall be taken accordingly.

\section{ACKNOWLEDGEMENTS}

This research was carried out under a collaborative research project, "Policy development for improvement of wood self-sufficiency ratio and the socio-economic effects on mountainous areas in East Asia" with financial support from JSPS ((B) 25292090).

\section{REFERENCES}

Gyeong Taek Min. Cheol Soo Jang and Gyeong Tae Heo. 2011 Policy Task for Timber Supply and Demand in Response to Climate Change. Korea Rural Economic Institute Research Report

Korea Forest Research Institute. 2007 Tendency and Periodic Prospect of Forest Area

Korea Forest Service. 2011 Timber Industry Promotion Plan (2012-2016)

Korea Forest Service. 20122011 Report on the Investigation of Timber Utilization Status as of 2011

Korea Forest Service. 2013a Prospective of Timber Supply and Demand in 2013 (Draft). Internal Data

Korea Forest Service. 2014b Annual Report on the Forest and the Trend of Forestry in 2013

Korea Timber Panel Association. 2013 Plywood and Board Statistics

Rin Won Joo. Seong Yeon Lee and Hyeon Seon Jeon. 1998 Forecast of Korean Log, Sawn Timber, and Plywood Market Trend. Collection of Forest Science Journal, 55: 93-103

Rin Won Joo. 2004 Trend and Prospect of Timber Supply and Demand in Korea. Symposium Data of Korea Forest Research Institute

Sang Gi Jeong. Yong Bae Park and Gyu Cheol Seong. 1997 Current Status of Timber Supply and Demand in Korea. Korea Forest Research Institute Research Data

Sang Min Lee. Cheol Soo Jang and Gyeong Deok Kim. 2008 Development of Timber Supply and Demand Model and Prospect. Korea Rural Economic Institute Research Report

Sang Min Lee, Gyeong Deok Kim and Seong Hwan Song. 2013 Development of Forest Product Supply and Demand Model and Prospect. Korea Rural Economic Institute Research Report

Soo Im Choi. Akinori Okamori and Masahiro Sakai. 2011 Trend of Timber Supply and Demand in Korea Until the Asian Economic Crisis. Science Bulletin of the Faculty of Agriculture Kyushu University, $\mathbf{5 5}(2)$ : 297-306 